\title{
SHRIMP U-Pb single zircon geochronology of a Proterozoic mafic dyke, Isukasia, southern West Greenland
}

\author{
A. P. NUTMAN, H. HAGIYA AND S. MARUYAMA
}

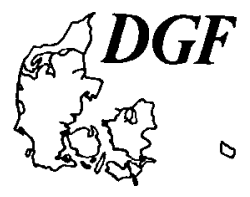

Nutman, A. P., Hagiya, H. \& Maruyama, S.: SHRIMP U-Pb single zircon geochronology of a Proterozoic mafic dyke, Isukasia, southern West Greenland. Bulletin of the Geological Society of Denmark. vol. 42, pp. 17-22. Copenhagen 1995-10-31.

https://doi.org/10.37570/bgsd-1995-42-02

Noritic dykes which are orientated north-south are early members of the Proterozoic dyke swarms which cut the Archaean craton of West Greenland. A diffuse-margined felsic patch within a $>100 \mathrm{~m}$ wide dyke at Isukasia is interpreted to have crystallised at the same time as the rest of the dyke. Three zircons were separated from a $500 \mathrm{~g}$ sample of the felsic patch. Two of the grains are prismatic, euhedral, metamict with very high $U$ contents, and are interpreted to have crystallised at the same time as the felsic patch. The most concordant analyses from the first two grains yield a weighted mean ${ }^{207} \mathrm{~Pb} /{ }^{206} \mathrm{~Pb}$ age of $2214 \pm 10 \mathrm{Ma}(2 \mathrm{~F})$. The third grain is somewhat rounded, non-metamict with a low $U$ content, and four spots yield ${ }^{207} \mathrm{~Pb} / 206 \mathrm{~Pb}$ ages between 3390 and $3310 \mathrm{Ma}$. This is within error of whole-rock $\mathrm{Rb}-\mathrm{Sr}$ and $\mathrm{Sm}-\mathrm{Nd}$ isochron ages (with large uncertainties) for pegmatites forming part of the country rocks to the dyke. $2214 \pm 10 \mathrm{Ma}$ is interpreted as the time of emplacement and crystallisation of the dyke. during which it assimilated blocks of country rocks, giving rise to the felsic patches and inherited zircons such as the $>3300$ Ma grain.

Allen P. Nutman, Research School of Earth Sciences, Australian National University, Canberra, Australia. Hiroshi Hagiya, Department of Earth Science and Astronomy, University of Tokyo at Komaba, Meguro-ku. Tokyo, Japan. Shigenori Maruyama, Department of Earth and Planetary Sciences, Tokyo Institute of Technology, Meguro-ku, Tokyo, Japan. June 1st, 1993.

\section{Introduction}

Basic dykes, collectively named the "MD" (metadolerite) dyke swarm (Bridgwater et al. 1976) are abundant in the Archaean craton of southern West Greenland (Fig. 1). They represent a crustal dilation of ca $0.2 \%$ (Hall \& Hughes, 1987). Many of the dykes are 20 to $100 \mathrm{~m}$ wide and extend for several tens of kilometres. Nearly all are steeply inclined or vertical, and chilled contacts with the host Archaean gneisses are widely preserved. Wholerock geochronology on sets of these dykes yield ages of ca. 2100 Ma but with large uncertainties (Bridgwater et al., 1985; Kalsbeek \& Taylor, 1985). Detailed study of cross-cutting relationships has provided a relative chronology of several dyke generations (Berthelsen \& Bridgwater, 1960; Chadwick, 1969; Hall et al., 1985). From the field relationships, the oldest of these dyke swarms comprise two types, one noritic and the other doleritic. The noritic dykes are most abundant in the northern part of the craton whilst the doleritic ones are most abundant to the south (Hall \& Hughes, 1986; 1987).

The noritic dykes are of considerable interest because of their high $\mathrm{MgO}$ (ca. $16 \mathrm{wt} \%), \mathrm{Cr}$ and Ni contents combined with high light rare earth element (REE) and large ion lithophile (LIL) element concentrations, non radiogenic whole-rock $\mathrm{Pb}$ and elevated initial ${ }^{87} \mathrm{Sr} /$ ${ }^{86} \mathrm{Sr}$ ratios (Hall \& Hughes, 1987; Bridgwater et al., $1985,1991)$. The dyke studied in most detail is in the Isukasia area and is one of the longest of these dykes, and is up to $200 \mathrm{~m}$ wide (Fig. 1). The Rb-Sr results from this dyke do not form a true isochron, but scatter about a "best fit" reference line of $2056 \mathrm{Ma}$ (Wagner, 1982). The $\mathrm{Pb}$ isotopic variation is not systematic, with many of the determinations displaying low ${ }^{207} \mathrm{~Pb} /{ }^{204} \mathrm{~Pb}$ values (Wagner, 1982). A Nd depleted-mantle model age of ca. $3100 \mathrm{Ma}$ has also been obtained on this dyke (Bridgwater et al., 1991). Two explanations of these characteristics have been offered. First, these dykes were derived at least in part from mantle that was metasomatically "enriched" in the Archaean (Hall \& Hughes, 1987) and second, they are the products of magmas which were contaminated by local Archaean crust during their ascent (Bridgwater et al.,1985).

In this paper we report $\mathrm{U}-\mathrm{Pb}$ zircon dating of a comagmatic, felsic igneous segregation in one of the longest noritic dykes in the Isukasia area (Fig. 1). The purpose of this is to obtain an accurate zircon age of emplacement of a noritic dyke which can be used in 


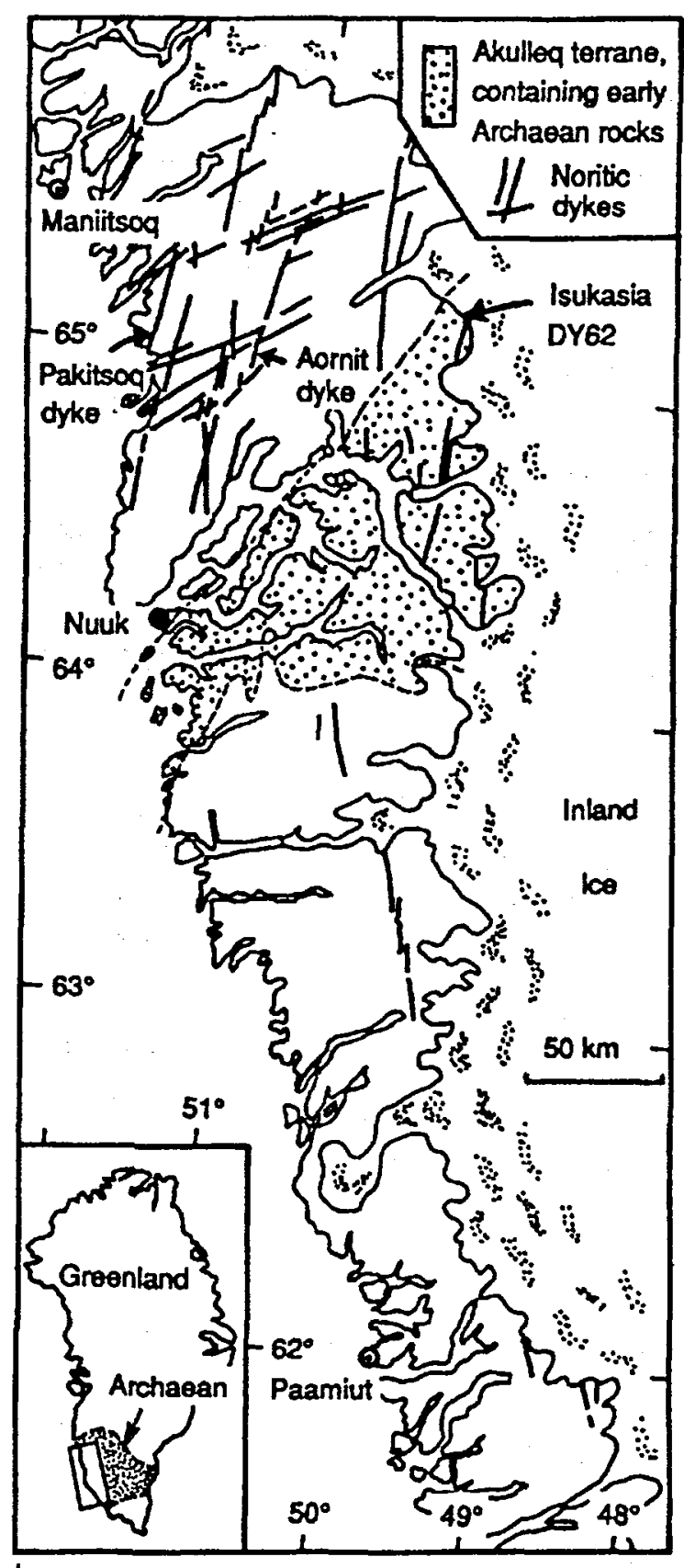

Fig. 1. Geological map of the Archaean craton and Isukasia, West Greenland.

modelling of the whole rock isotopic data. The presence of any zircons inherited from dyke's country rocks would suggest that contamination by country rocks played a part in giving these dykes their distinct geochemical and isotopic signatures.

\section{Isukasia dyke}

A north-south trending noritic dyke cuts the Isua supracrustal rocks and the Amittsoq gneisses of the Isukasia area. It is locally offset by en echelon relationships, but can be traced for at least $20 \mathrm{~km}$ close to the Inland Ice. This dyke was sampled where it cuts the Isua supracrustal belt (Fig. 1). The country rocks are predominantly mafic in composition, with some units of banded iron formation and also some veins of pegmatite and granitoid. The dyke has steep, sharp contacts with chilled marginal facies of fine-grained norite, partly altered to chlorite + actinolite + epidote + albite rock. The dyke may be classified as being dominated by augite norite with lesser amounts of augite granophyre. Weathered surfaces are brownish, and it is traversed by various-sized diffuse-margined white patches and veins which do not extend into the country rocks. This dyke is slightly enriched in $\mathrm{SiO}_{2}$ compared with typical noritic dykes in southern West Greenland reported by Hall \& Hughes (1987). Mediumgrained $(1-4 \mathrm{~mm})$ orthopyroxene and clinopyroxene (partly altered to amphiboles) and plagioclase form a mosaic of grains surrounded by a finer-grained matrix of quartz, plagioclase (oligoclase-albite), K-feldspar, biotite, Fe-Ti oxide, hornblende and apatite. Orthopyroxene is absent from the most felsic samples of the dyke. Orthopyroxenes are concentrically zoned from bronzite cores (e.g. $\mathrm{En}_{86} \mathrm{Fs}_{10} \mathrm{Wo}_{04}$ ) to hypersthene rims (e.g. $\mathrm{En}_{66} \mathrm{Fs}_{30} \mathrm{Wo}_{04}$ ). The clinopyroxene is augite (e.g. $\mathrm{En}_{55} \mathrm{Fs}_{10} \mathrm{Wo}_{35}$ ). Medium-grained plagioclase varies from $\mathrm{An}_{65}$ to $\mathrm{An}_{45}$ with normal zoning.

Sample DY62 was collected from the (irregular) margin of a large ( 2 by $3 \mathrm{~m}$ ) white $K$-feldspathic granophyre patch. The rim of this patch is dark coloured and relatively fine-grained $(0.5$ to $2 \mathrm{~mm})$. whilst its core is white and contains coarse-grained (2 to $5 \mathrm{~mm}$ ) euhedral orthoclase. Both core and rim display the same granophyric texture. Fine-grained biotite, hornblende and epidote appear as aggregates up to $2 \mathrm{~mm}$ diameter, which also include apatite and zircon. The latter phase was confirmed by EDS analysis. Zircon separation of two splits of DY62 consisting of both the dark rim and white interior parts of the patch was undertaken by standard heavy liquid techniques. No zircons were recovered from one sample, whilst the other yielded three zircons from approximately $500 \mathrm{~g}$ of rock.

\section{SHRIMP U-Pb zircon geochronology}

\section{Analytical method}

$\mathrm{U}-\mathrm{Th}-\mathrm{Pb}$ isotopic ratios and absolute abundances in ca. $30 \mu \mathrm{m}$ diameter areas of zircons were analysed using the ion microprobe SHRIMP, and were referenced to the Australian National University standard zircon $\mathrm{SL} 13\left({ }^{206} \mathrm{~Pb} /{ }^{238} \mathrm{U}=0.0928 ; 572 \mathrm{Ma}\right)$. Repeated analyses of the standard during the analytical session was 
used to calculate the uncertainty in the interelement isotopic ratios of unknowns. Further details of the general analytical procedure are given by Compston et al. (1984) and Williams \& Claesson (1987). Ages have been calculated using the values for decay constants and present day ${ }^{238} U /{ }^{235} U$ recommended by the IUGS Subcommission on Geochronology (Steiger and Jäger, 1978).

Previously, counting statistics alone has been used as an estimate of error on the measured ratios. This has always been understood to be a minimum estimate of error, and in low $\mathrm{U}$, non metamict, low common $\mathrm{Pb}$ zircon is a reasonable approximation. However, in either high Th-U or metamict damaged zircon sites ion count rates in successive nass-scans commonly vary well beyond the scatter expected from counting statistics alone (the ratio between the observed and expected variance, $F$, exceeds about 2.5 ). This is due to target heterogeneity on the sub-micron scale. Modification to the SHRIMP data processing programs by Trevor Ireland that augments the counting error by $\sqrt{F}$ has been applied to the data presented here.

We have taken Cumming \& Richards (1975) linear model III $2200 \mathrm{Ma} \mathrm{Pb}$ as the common $\mathrm{Pb}$ composition. However, as most analysed sites have very low proportions of common $\mathrm{Pb}$, the calculated ages are insensitive to the choice of common $\mathrm{Pb}$ composition.

\section{Prismatic, metamict grains}

Grains 2 and 3 are euhedral, with extremely high $U$ contents (2200-4900 ppm). Grain 2 is prismatic, yellow in colour and approximately $200 \mu \mathrm{m}$ long and grain 3 is opaque and is approximately $100 \mu \mathrm{m}$ long. These characteristics (including high $U$ content) are typical of zircons found in low abundance in noritic dykes and felsic patches and veins within them (Black et al.,

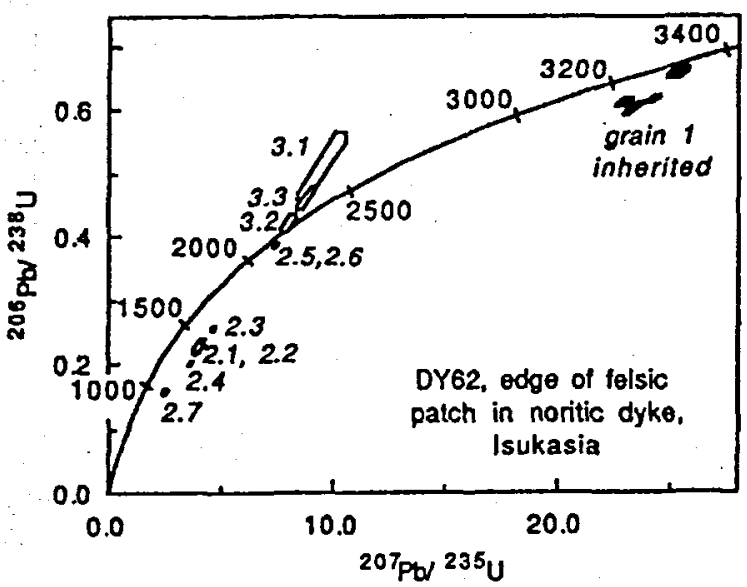

Fig. 2. U-pb concordia plot for zircons in dyke samples DY62.
1991; Lanyon et al., 1993). Both grains 2 and 3 from sample DY62 contain extensive metamict domains which could not be avoided totally during analysis. Seven analyses on grain 2 and 3 analyses on grain 3 were done. All these analyses show low proportions of common $\mathrm{Pb}$. All the corrected ${ }^{207} \mathrm{~Pb} /{ }^{006} \mathrm{~Pb}$ ages lie between 1800-2220 Ma (Table 1). Analyses of grain 2 range from almost concordant to strongly normal discordant, and analyses of grain 3 are all reverse discordant (Fig. 3).

The observed reverse discordance could be due to several causes:

1) Because the ion-sputtering process gives differential yields of $\mathrm{Pb}$ and $\mathrm{U}$ species from the target zircon, $\mathrm{U}-\mathrm{Pb}$ isotopic ratios are calibrated using a relationship between measured ${ }^{206} \mathrm{~Pb} /{ }^{238} \mathrm{U}$ and $\mathrm{UO} /$
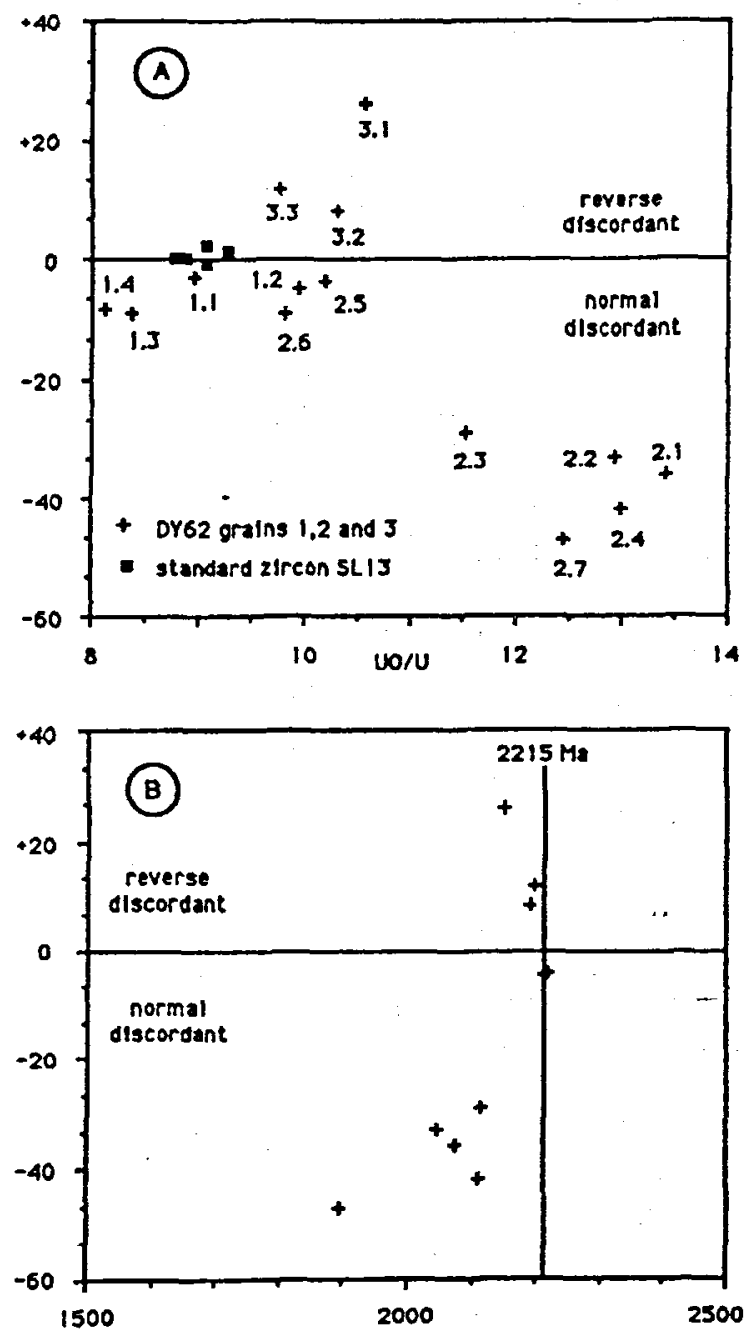

Fig. 3. A: Discordance $\left(-\left[{ }^{206} \mathrm{~Pb} /{ }^{208} \mathrm{U}\right.\right.$ age $\left./^{207} \mathrm{~Pb} /{ }^{206} \mathrm{~Pb}\right] \times 100$ versus UO/U and $\mathrm{B}$ : Discordance versus ${ }^{207} \mathrm{~Pb} /{ }^{206} \mathrm{~Pb}$ age for DY62 zircons. 
Table 1. SHRIMP U-Pb zircon data for Isukasia dyke sample DY62. Isotopic ratios are after removal of small amounts of common lead, using the ${ }^{204} \mathrm{~Pb}$ correction method. The common $\mathrm{Pb}$ composition used is Cumming \& Richards (1975) linear model III $2200 \mathrm{Ma} \mathrm{Pb}$. Uncertainties are given at the IF level. Disc \% is discordance $\left(1-{ }^{206} \mathrm{~Pb} /{ }^{38} \mathrm{U}\right.$ age/ $\left.{ }^{207} \mathrm{~Pb} /{ }^{206} \mathrm{~Pb} a g e\right) \mathrm{x}$ 100.

\begin{tabular}{lllllllllll}
\hline Site & $\begin{array}{l}\mathrm{U} \\
(\mathrm{ppm})\end{array}$ & $\begin{array}{l}\text { Th } \\
(\mathrm{ppm})\end{array}$ & $\mathrm{Th} / \mathrm{U}$ & $\begin{array}{l}{ }^{204} \mathrm{~Pb} \\
(\mathrm{ppb})\end{array}$ & $\begin{array}{l}\mathrm{Comm} . \\
{ }^{206} \mathrm{~Pb}(\%)\end{array}$ & ${ }^{206 \mathrm{~Pb} / 238 \mathrm{U}}$ & ${ }^{207} \mathrm{~Pb} /{ }^{235} \mathrm{U}$ & ${ }^{207} \mathrm{~Pb} /{ }^{206} \mathrm{~Pb}$ & Age $(\mathrm{Ma})$ & disc. \\
\hline $1-1$ & 248 & 61 & 0.25 & $<1$ & $<0.01$ & $0.603 \pm 11$ & $23.38 \pm 0.47$ & $0.2814 \pm 17$ & $3370 \pm 09$ & -10 \\
$1-2$ & 59 & 19 & 0.32 & 11 & 0.47 & $0.659 \pm 08$ & $25.34 \pm 0.50$ & $0.2791 \pm 37$ & $3358 \pm 21$ & -3 \\
$1-3$ & 158 & 55 & 0.35 & 3 & 0.05 & $0.618 \pm 07$ & $24.22 \pm 0.35$ & $0.2844 \pm 21$ & $3387 \pm 12$ & -8 \\
$1-4$ & 129 & 52 & 0.41 & 2 & 0.04 & $0.613 \pm 08$ & $22.94 \pm 0.42$ & $0.2715 \pm 31$ & $3315 \pm 18$ & -7 \\
$2-1$ & 3505 & 4722 & 1.35 & 125 & 0.28 & $0.216 \pm 03$ & $3.83 \pm 0.06$ & $0.1288 \pm 10$ & $2082 \pm 13$ & -39 \\
$2-2$ & 2306 & 2288 & 0.99 & 73 & 0.28 & $0.228 \pm 11$ & $4.02 \pm 0.26$ & $0.1281 \pm 48$ & $2072 \pm 65$ & -36 \\
$2-3$ & 3182 & 3249 & 1.02 & 140 & 0.30 & $0.255 \pm 03$ & $4.62 \pm 0.06$ & $0.1314 \pm 08$ & $2117 \pm 11$ & -31 \\
$2-4$ & 4863 & 7781 & 1.60 & 32 & 0.06 & $0.200 \pm 04$ & $3.64 \pm 0.10$ & $0.1316 \pm 18$ & $2120 \pm 24$ & -44 \\
$2-5$ & 3447 & 3241 & 0.94 & 185 & 0.24 & $0.386 \pm 05$ & $7.40 \pm 0.11$ & $0.1392 \pm 06$ & $2217 \pm 08$ & -5 \\
$2-6$ & 3550 & 3313 & 0.93 & 210 & 0.26 & $0.385 \pm 04$ & $7.38 \pm 0.09$ & $0.1388 \pm 05$ & $2213 \pm 06$ & -5 \\
$2-7$ & 4692 & 7506 & 1.60 & 1526 & 3.42 & $0.158 \pm 04$ & $2.51 \pm 0.15$ & $0.1156 \pm 06$ & $0889 \pm 89$ & -50 \\
$3-1$ & 4235 & 6172 & 1.46 & 219 & 0.17 & $0.511 \pm 54$ & $9.47 \pm 1.10$ & $0.1346 \pm 47$ & $2157 \pm 62$ & 23 \\
$3-2$ & 4364 & 6937 & 1.59 & 296 & 0.27 & $0.423 \pm 14$ & $7.99 \pm 0.35$ & $0.1370 \pm 32$ & $2190 \pm 40$. \\
$3-3$ & 4037 & 1134 & 0.28 & 339 & 0.31 & $0.462 \pm 19$ & $8.80 \pm 0.41$ & $0.1384 \pm 26$ & $2207 \pm 33$ & 11 \\
\hline
\end{tabular}

U, using the standard zircon SL13 analyses (Williams and Claesson, 1987). In the case of the Isukasia dyke data, both apparently reverse and normal discordant analyses of grains 2 and 3 have considerably higher UO/U values than the standard (Fig. 3a). The extrapolation of the calibration curve to these high $U O / U$ values reduces our confidence in the accuracy of the calculated $\mathrm{U}-\mathrm{Pb}$ ratios for these analyses:

2) Perhaps in damaged, metamict, high U domains, sputtering of ${ }^{206} \mathrm{~Pb}^{+}$relative to ${ }^{238} \mathrm{U}^{+}$ions is more efficient than in undamaged zircon, giving rise to reverse discordance. This possibility was first suggested on the basis of a reconnaissance SHRIMP and TEM microstructural study of high-U zircon (McClaren et al., 1990). Both these factors can be regarded as site-specific matrix effects on damaged, metamict, high-U zircon.

3) Assessment should also be made whether the reverse discordance could be genuine, due to unsupported radiogenic $\mathrm{Pb}$. An example of this has been documented in an early Archaean gneiss from Mount Sones, Antarctica (Williams et al., 1984), where domains within early Archaean zircons gained their excess radiogenic $\mathrm{Pb}$ from neighbouring areas in an Archaean event (in this case at ca. $2500 \mathrm{Ma}$ ), giving rise to reverse discordant points which also show the highest ${ }^{207} \mathrm{~Pb} /{ }^{06} \mathrm{~Pb}$ ages. For the Isukasia dyke analyses sites which show apparent normal discordance have somewhat lower ${ }^{207} \mathrm{~Pb} /{ }^{06} \mathrm{~Pb}$ ages than the least discordant analyses, indicating ancient $\mathrm{Pb}$ loss (Fig. 3b). On the other hand, the reverse discordant analyses have indistinguishable ${ }^{207} \mathrm{~Pb} /{ }^{206} \mathrm{~Pb}$ ages to the most concordant analyses (Table 1 and
Fig. 3b). Thus reverse discordance is not due to unsupported radiogenic $\mathrm{Pb}$, obtained in an ancient event. Instead, we conclude that the reverse concordance problem is due to site-pecific matrix affects during analysis of high-U metamict zircon, leading to inaccurate determination of U-Pb ratios. It is stressed that this problem is restricted to types of zircons which, if others are available, would definitely not be analysed. Furthermore, this problem does not affect ${ }^{207} \mathrm{~Pb}{ }^{206} \mathrm{~Pb}$ ratios, where both species are measured directly using SHRIMP without the need for calibration against a standard.

Further discussion of these grains is restricted to analyses $2.5,2.6$ and 3.2 , which show $\mathrm{UO} / \mathrm{O}$ values closest to those obtained on the standard SL13, the lowest degrees of apparent discordance and comparatively small uncertainties due to the variance ratio between observed and expected errors in ion counting of each measured mass being low. These analyses have mutually indistinguishable ${ }^{207} \mathrm{~Pb} /{ }^{206} \mathrm{~Pb}$ values and yield a weighted mean ${ }^{207} \mathrm{~Pb} /{ }^{206} \mathrm{~Pb}$ age of $2214 \pm 10 \mathrm{Ma}(2 \mathrm{~F})$. Combined with the petrologic evidence given above, this age is interpreted asthe best estimate of the time of crystallisation of the dyke.

\section{Rounded, non-metamict grain}

Grain 1 (ca $150 \mu$ long) is half of a distinctly rounded, red-brown zircon, with low to moderate $U$ content (between 50 and $250 \mathrm{ppm}$ ). The four analyses of this grain range from concordant to slightly discordant, with low common $\mathrm{Pb}$ content and ${ }^{207} \mathrm{~Pb} /{ }^{06} \mathrm{~Pb}(2 \sigma)$ ages between $3315 \pm 36 \mathrm{Ma}$ and $3387 \pm 24 \mathrm{Ma}$ (Fig. 2, Table 1). This grain, with its rounded morphology and 
spread in ${ }^{207} \mathrm{~Pb} /{ }^{206} \mathrm{~Pb}$ ages, is interpreted as an inherited grain with a minimum age of $3387 \pm 24$ Ma which has suffered variable degrees of ancient $\mathrm{Pb}$-loss, perhaps at $2214 \mathrm{Ma}$ when it was incorporated into the dyke.

\section{Discussion}

Given the low yield of zircon from the sample, some thought should be given to the possibility that all three grains are laboratory contaminants. Laboratory contaminants are likely to have been derived from granitic rocks or sediments, normally with lower (<1000 p.p.m) Th andU contents and less likely to be metamict. On the other hand, the chemistry and habit of grains 2 and 3 are like those extracted from other noritic dykes (Black et al., 1991; Lanyon et al., 1993). Although the U-Th contents and morphology of grain 1 are more "normal", its age (3315-3387 Ma) matches that of some of the country rocks of the dyke, and it is therefore best interpreted as belonging to the dyke sample rather than being a laboratory contaminant.

The field and petrographic observations combined with the zircon geochronology suggest that the dyke is ca. $2214 \mathrm{Ma}$ old. The ${ }^{207} \mathrm{~Pb}{ }^{206} \mathrm{~Pb}$ ages obtained from grain 1 of between 3310 and $3390 \mathrm{Ma}$ (Table 1) agree with $\mathrm{Sm}-\mathrm{Nd}$ and $\mathrm{Rb}-\mathrm{Sr}$ whole rock isochron ages of $3362 \pm 62 \mathrm{Ma}$ and $3382 \pm 81 \mathrm{Ma}$ respectively (Baadsgaard et al., 1986), of pegmatite dykes which cut the Isua supracrustal belt. Furthermore, the sampled dyke contains diffuse-margined blocks of foliated, granitic pegmatite. Assimilation and partial melting of these felsic inclusions did not proceed to completion, leaving some inclusions of country rocks intact, plus felsic patches such as DY62 which did not completely mix with the mafic magma. We suggest that $>3300 \mathrm{Ma}$ zircons such as grain 1 became incorporated into the dyke magma by such a mechanism

All the Proterozoic noritic dykes are enriched in the LIL elements and LREE compared with tholeiitic dykes (e.g., Hall \& Hughes, 1987; Bridgwater et al., 1985). They also show anomalously old (Archaean) DM model $\mathrm{Nd}$ ages, high initial ${ }^{87} \mathrm{Sr} /{ }^{86} \mathrm{Sr}$ ratios and unradiogenic, low ${ }^{207} \mathrm{~Pb} /{ }^{206} \mathrm{~Pb}$ values (Bridgwater et al., 1991). The Isukasia dyke which cuts early Archaean rocks shows an older DM Nd model age ( $>3100 \mathrm{Ma})$, the highest initial ${ }^{87} \mathrm{Sr} /{ }^{86} \mathrm{Sr}$ ratio and the lower ${ }^{207} \mathrm{~Pb} /{ }^{206} \mathrm{~Pb}$ values, compared with the Pakitsoq and Aornit dykes (e.g. DM model Nd age of $2700 \mathrm{Ma}$ for Pakitsoq dyke) which cut a middle to late Archaean terrane in the west (Fig. 1; Bridgwater et al., 1991). Thus there may be a correlation between the isotopic signature of the dykes and the age of their country rocks. Combined with finding a $>3300 \mathrm{Ma}$ inherited zircon in the Isukasia dyke, we conclude that the noritic magma did assimilate country rocks during its passage through the crust However, this conclusion does not rule out the possibility that prior to interaction with contin- ental crust, the parental magmas of the noritic and tholeiitic dykes already showed different isotopic, LIL and REE signatures, inherited from their mantle sources.

\section{Acknowledgments}

Prof. W Compston made the ion-probe SHRIMP available for geochronological work for the Japanesesponsored Early Earth History project. R. Rudowski is thanked for fastidious heavy mineral separation. Reviews by D. Bridgwater and S. Claesson improved the manuscript.

\section{References}

Baadsgaard, H.. Nutman, A. P. \& Bridgwater, D., 1986: Geochronology and isotopic variation of the early Archaean Amîtsoq gneisses of the Isukasia area, southern West Greenland Geochimica Cosmochirnica Acta 50, 21732183.

Berthelsen, A \& Bridgwater, D., 1960: On the field occurrence and petrography of some basic dykes of supposed preCambrian ape from the southern Sukkertoppen district western Greenland. Bulletin Grønlands geologiske Unders $\varnothing$ gelse $24,43 \mathrm{pp}$.

Black. L. P., Kinny, P. D. \& Sheraton. J. W. 1991: The difficulties of dating mafic dykes: an Antarctic example. Contributions to Mineralogy and Petrology 109, 183-194.

Bridgwater, D., Fryer. B. \& German. B. E. 1985: Proterozoic basic dykes in southern Greenland and the coast of Labrador: tectonic setting, intrusion forms and chernistry. Proceedings International Conference on Mafic Dyke Swarms, University of Toronto, 15-21.

Bridgwater, D., Keto, L., McGregor, V. R \& Myers, J. S. 1976: Archaean gneiss complex of Greenland In Escher, A., Watt, W. S. (ed) Geology of Greenland. 19-75. Copenhagen: Geological Survey of Greenland.

Bridgwater, D., Mengel F, Fryer, B. \& Wagner, P., 1991: LILE enriched, high magnesium, early Proterozoic dykes in the North Atlantic shield: Crustal contamination in deep seated magma chambers versus derivation from enriched mantle sources as illustrated by $2.1 \mathrm{Ga}$ dykes from $\mathrm{SW}$ Greenland. Abstracts volume. ECSOOT meeting, Dartmouth. Nova Scotia 1991.

Chadwick, B.. 1969: Patterns of frachture and dyke intrusion near Frederikshab, Southwest Greenland. Tectonophysics 8, 247-264.

Compston, W, Williams, I. S. \& Meyer, C., 1984: U-Pb geochronology of zircons from lunar breccia 73217 using a sensitive high mass-resolution ion microprobe. Journal of Geophysical Research 89 supplement B. 525-534.

Cumming, G. L. \& Richards, J. R., 1975: Ore lead ratios in a continuously changing earth. Earth Planetary Science Letters 28. 155-171.

Friend. C. R. L. \& Nutman, A. P., 1988: Refolded nappes formed during late Archaean terrane assembly, Godthåbsfjord, southern West Greenland. Journal Geological Society London 148, 507-519. 
Hall, R. P. \& Hughes. D. J., 1986: A boninitic dyke in the eastern Sukkertoppen region: geochemistry of the boninitic-noritic dyke swarm of southern West Greenland. Rapport Grønlands geologiske Unders $\varnothing$ gelse 130, 44-52.

Hall. R. P. \& Hughes. D. J., 1987: Noritic dykes of southern West Greenland: early Proterozoic bonititic magmatism. Contributions Mineralogy Petrology 97, 169-182.

Hall, R. P., Hughes, D. J. \& Friend, C. R. L., 1985: Geochemical evolution and unusual pyroxene chemistry of the MD tholeiite dyke swarm from the Archaean craton of southern West Greenland. Journal Petrology 26, 252-282

Kalsbeek, F. \& Taylor, P. N., 1985: Age and origin of early Proterozoic dolerite dykes in South-West Greenland. Contributions Mineralogy Petrology 89, 307-316.

Lanyon, R., Black, L. P. \& Seitz, N-M., 1993: U-Pb zircon dating of mafic dykes and its implication to the Proterozoic geological history of the Vestfold Hills, East Antarctica, Contributions Mineralogy Petrology 115. 184-203.

McClaren, A. C., Fitz Gerald, J. \& Williams. I. S., 1990: The microstruchm of zircon and its influence on the $\mathrm{Pb} /$ $U$ age measured by the ion microprobe. Seventh International Conference on Geochronology, Cosmochronology and Isotope Geology, Geological Society Australia Abstract 27, p. 65.

Steiger, R. H. \& Jäger, E., 1977: Subcommission on geochronology: convention on the use of decay constants in geoand cosmochronology. Earth Planetary Science Letters 36. $359-362$.

Williams, I. S., W. Compston, L. P. Black, T. R Ireland \& J. $\mathrm{J}$. Foster. 1984: Unsupported radiogenic $\mathrm{Pb}$ in zircon: a cause of anomalously high $\mathrm{Pb}-\mathrm{Pb}, \mathrm{U}-\mathrm{Pb}$ and $\mathrm{Th}-\mathrm{Pb}$ ages. Contributions Mineralogy Petrology 88, 322-327.

Williams, I. S. \& Claesson, S., 1987: Isotopic evidence for the Precambrian provenance and Calcdonian metamorphism of the high grade paragneisses from the Seve Nappes. Scandinavian Caledonides. II. Ion microprobe zircon U-Th-Pb. Contributions Mineralogy Petrology 97, 205217. 